Published in final edited form as:

Crit Care Clin. 2015 July ; 31(3): 473-495. doi:10.1016/j.ccc.2015.03.005.

\title{
Congestive Heart Failure and Central Sleep Apnea
}

\author{
Scott A. Sands, PhD and \\ Division of Sleep Medicine, Brigham and Women's Hospital \& Harvard Medical School, Boston, \\ MA \\ Department of Allergy, Immunology and Respiratory Medicine and Central Clinical School, Alfred \\ Hospital and Monash University, Melbourne, Australia \\ Robert L. Owens, MD \\ Division of Pulmonary and Critical Care Medicine, University of California, San Diego, La Jolla, \\ CA
}

\section{Keywords}

Congestive heart failure; Central sleep apnea; cheyne stokes respiration; loop gain

\section{Clinical Considerations}

\section{Historical perspective}

An abnormal respiratory pattern has long been recognized as an ominous sign of congestive heart failure. The observations of three physicians who have lent their names to the pattern remain informative:

"His breathing was very particular: he would cease breathing for twenty or thirty seconds, and then begin to breathe softly, which increased until he breathed extremely strong, or rather with violent strength, which gradually died away till we could not observe that he breathed at all. He could not lie down without running the risk of being suffocated, therefore he was obliged to sit up in his chair."

John Hunter, 1781 (1)

"The patient suddenly developed palpitations and displayed signs of severe congestive heart failure. The only particularity in the last period of his illness, which lasted eight or nine days, was in the state of respiration. For several days his breathing was irregular; it would entirely cease for a quarter of a minute, then it would become perceptible, though very low, then by degrees it became heaving and quick, and then it would gradually cease again. This revolution in the state of his breathing occupied about a minute, during which there were about thirty acts of respiration."

Publisher's Disclaimer: This is a PDF file of an unedited manuscript that has been accepted for publication. As a service to our customers we are providing this early version of the manuscript. The manuscript will undergo copyediting, typesetting, and review of the resulting proof before it is published in its final citable form. Please note that during the production process errors may be discovered which could affect the content, and all legal disclaimers that apply to the journal pertain. 
John Cheyne, 1818

"This symptom [periodic breathing], as occurring in its highest degree, I have only seen during a few weeks previous to the death of the patient."

William Stokes, 1854

The initial observations by Hunter, Cheyne and Stokes were made in patients close to death. They were the first to note the characteristic waxing and waning respiratory pattern of "Cheyne-Stokes respiration" (CSR), a common pattern of central sleep apnea (CSA) in patients with congestive heart failure (CHF). CSR is characterized by complete cessation of respiratory effort and airflow (apnea phase) alternating with profound hyperventilation (hyperventilation phase). Such patterns occur during wakefulness but are typically more prominent during sleep. (Figure 1) The apnea phase of Cheyne-Stokes respiration (CSR) causes arterial hypoxemia, and the hyperventilation phase produces surges in blood pressure, arousal from sleep and dyspnea. (2-5) (Figure 2). Typically CSR has a periodicity of 45-90 seconds, and occurs during non rapid eye movement (NREM) sleep stages 1 and 2. CSR severity is typically measured by quantifying the percent of total sleep time in CSR, and by the number of apneas and central hypopneas per hour of sleep (apnea-hypopnea index, AHI). (6) Despite advances in the treatment of congestive heart failure (e.g. beta-blockade, spironolactone), untreated CSR remains highly prevalent during sleep and retains its association with increased morbidity and mortality independent of heart failure severity (710). (Boxes 1-4)

\section{Epidemiology in stable CHF}

One of the first rigorous studies to use polysomnography by Javaheri and colleagues found a high prevalence (40\%) of CSR in patients with systolic heart failure. (11) This prevalence has been a relatively consistent finding depending on the population studied (with increased prevalence with worsening heart failure) and the threshold and technology used to diagnosis sleep disordered breathing. (12-15) Although early epidemiological studies pre-dated the widespread use of advanced heart failure therapies, even the most recent studies continue to show a consistently high prevalence of CSR. $(14,16)$ CSR is also not limited to systolic heart failure; CSR is common in patients with symptomatic heart failure with preserved ejection fraction (17) (diastolic dysfunction), and is also common in patients with asymptomatic systolic dysfunction (18). Additional risk factors for CSR include male gender, older age, the presence of atrial fibrillation, nocturnal ventricular arrhythmias, low arterial $\mathrm{PCO}_{2}\left(\mathrm{PaCO}_{2}\right)$, dyspnea with minimal exertion (NYHA class $\underset{\mathrm{II}}{\mathrm{I}}$ ), nocturnal dyspnea, very low ejection fraction $(\mathrm{EF}<20 \%)$, left atrial enlargement, and high NT-proBNP $(5,10,12,14,15,19,20)$.

\section{CHF in the ICU}

Congestive heart failure is one of the most common causes of admission to hospitals in the United States, especially in those over 65 years of age, with over 1 million hospital admissions per year. (21) Approximately 10\% of these patients will require ICU admission. (22) Despite the high number of hospital/ICU admissions, there are few data regarding the prevalence of CSR among hospitalized patients. Hoffman and colleagues noted CSR in 44\% 
of CHF patients after weaning from mechanical ventilation for cardiogenic pulmonary edema (23). More recently Padeletti and colleagues found moderate-severe CSR (AHI>15) in $75 \%$ of patients admitted for an acute exacerbation of systolic congestive heart failure, with an average of $51 \%$ of total sleep time spent exhibiting CSR. Thus, CSR appears to be more prevalent ( $75 \%$ ) in decompensated CHF in inpatients than in stable CHF outpatients $(\sim 40 \%)$.

Unfortunately, data on CSR prevalence in the ICU and effects on outcomes are lacking. Given the pathophysiological changes that occur in severe heart failure (that requires ICU admission for management) we might expect a very high rate of CSR. However, the most acutely ill patients may be on mechanical ventilation and sedated, often with narcotics. Mechanical ventilation will also provide ventilatory and cardiac support for the patient in heart failure, as both cardiac preload and afterload will be reduced while on positive endexpiratory pressure (PEEP). $(24,25)$ Thus, CSR is likely to be most relevant during the process of ventilator weaning (23) when such support is removed. It will be during the process of moving toward liberation from mechanical ventilation that sedatives will be decreased, PEEP and supplemental oxygen levels will be lowered, and patients will be placed on spontaneous modes (i.e. patient triggered) of ventilation.

\section{Pathophysiological Considerations}

\section{Control of breathing}

The physiological control of breathing is a negative feedback system that acts to regulate acid-base status and the partial pressure of arterial carbon dioxide $\left(\mathrm{PaCO}_{2}\right)$, and maintain adequate oxygenation. The primary components of the control of breathing system are chemoreceptor inputs located in the medulla which respond to changes in acid-base status and the peripheral chemoreceptors in the carotid bodies that are sensitive to both changes in $\mathrm{PaO}_{2}$ and $\mathrm{PaCO}_{2}$. Central and peripheral chemoreceptor inputs are integrated in the medulla and act to modulate breath amplitude (and timing to a lesser extent), ultimately resulting in a level of ventilation conducive to survival. Importantly, there are other sensors in the lungs and circulation whose inputs modify the behavior of the respiratory control system, including pulmonary stretch receptors, irritant receptors, and the " $\mathrm{J}$ " (juxta-capillary) receptors which may become important in disease states and which are discussed below. $(26-30)$

\section{The concept of loop gain}

The stability of the respiratory feedback loop has been quantified using the engineering criterion, loop gain. Briefly, loop gain is defined as the magnitude of the ventilatory response of the respiratory control system to a sinusoidal respiratory disturbance (at the frequency of CSR). Feedback loops with a value of loop gain which exceeds 1.0 (response is greater than the disturbance) are intrinsically unstable and periodic oscillations in breathing will inevitably occur (Figure 3). When loop gain is $<1$ (response<disturbance), transient oscillations are attenuated and thereby temporary. Detailed descriptions of loop gain have been given previously (31-33). Consider a period of hyperventilation (disturbance) which causes a reduction in $\mathrm{PaCO}_{2}$. This reduction in $\mathrm{PaCO} 2$ is sensed by chemoreceptors after a 
circulatory delay, which will in turn elicit a later reduction in ventilatory drive (response). In an unstable system, the drop in ventilatory drive will cause a greater degree of hypoventilation than the original hyperventilatory disturbance. Oscillations will be amplified and self-sustained with no specific initiating factor required. The concept of loop gain has been successfully applied to predict the occurrence of CSR (Figure 4). (34) and the resistance to its suppression with treatment $(35,36)$.

Detailed analyses of the control system consistently reveal four primary factors that contribute to loop gain $(31,34,35,37-39)$, according to the relationship:

$$
\text { Loop gain }=\mathrm{G} \frac{\mathrm{PaCO}_{2}}{\text { Lung Volume }} \mathrm{T} \text { (Equation 1) }
$$

where $\mathrm{G}$ is the chemosensitivity, defined as the change in ventilation in response to a change in $\mathrm{PaCO}_{2} ; \mathrm{PaCO}_{2}$ is the arterial partial pressure of $\mathrm{CO}_{2}$ (with the assumption here that inspired $\mathrm{PCO}_{2}=0$ ); Lung volume is the end-expiratory lung volume (e.g. functional residual capacity); and $\mathrm{T}$ is a timing factor which incorporates the lung-chemoreceptor circulatory delay. A similar equation can be written for the ventilatory feedback control of arterial $\mathrm{PO}_{2}$.

\section{How CHF predisposes to CSR}

Equation 1 provides the framework for identifying the factors that predispose an individual towards CSR. Indeed, there is evidence that each of these factors plays a role in the development or effective treatment of CSR.

\section{Circulatory delay}

Classically, an increased lung-to-chemoreceptor circulatory delay ( $\mathrm{T}$ ) has been implicated as the cause of CSR. Patients with heart failure can have elevated circulatory delay as a result of decreased cardiac output. CHF patients with a lower left ventricular ejection fraction, lower cardiac output, and elongated circulatory delays are at elevated risk of CSR $(11,19$, $40,41)$. Further evidence includes the observation that the lung-to-ear circulation delay (approximating the lung-to-chemoreceptor delay) is equal to the delay between the nadir $\mathrm{CO}_{2}$ level and apnea during CSR (42). Raising cardiac output with exercise, pharmacological intervention, or cardiac resynchronization can also reduce the ventilatory oscillations in CHF (43-45). However, such interventions may also effect other factors (Eq. 1) contributing to stabilization. Moreover, many CHF patients with low LVEF and increased circulatory delays do not have CSR (34). Thus, the other factors identified in Eq. 1 are likely important as well.

\section{Chemosensitivity}

Increased chemosensitivity $(G)$ is the most powerful determinant of CSR. (34, 46-48) Specifically, CHF-CSR severity is strongly associated with the dynamic ventilatory response to $\mathrm{CO}_{2}$ (48), suggesting an essential role for elevated peripheral chemoreceptor (carotid bodies) activity in CSR. Increased chemosensitivity is thought to be due to increased left atrial pressure (Figure 5) (49). Additional evidence includes: 
i. Raised PCWP is common in patients with CSR and is correlated with CSR severity $(41,45,49)$.

ii. CSR is associated with elevated NT-proBNP $(10,50)$, a biomarker of leftventricular stretch and elevated PCWP (51-54).

iii. Left atrial size is associated with CSR and chemosensitivity (55).

iv. PCWP is associated with hypocapnia (56), a marker of increased chemosensitivity (57) and predictor of CSR (12).

v. Raising left atrial pressure acutely increases chemosensitivity in dogs (58).

vi. CSR is associated with cardiogenic pulmonary edema in the form of reduced pulmonary diffusing capacity (59), presumably via increased pulmonary capillary pressure.

vii. CSR is linked with fluid status including the degree of overnight rostral fluid shift (60).

viii. The reduction in PCWP with vasodilator (nitroprusside) is linearly associated with the reduction in CSR (45).

Raised left atrial pressure is believed to increase chemosensitivity directly via stretch receptors in the left atrium or pulmonary vein $(30,61,62)$ and indirectly through pulmonary edema via juxtapulmonary capillary receptors ( $\mathrm{J}$ receptors, pulmonary $\mathrm{C}$-fibers). It is important to note, however, that such vagal afferents may not entirely explain hypersensitive chemoreflexes in CHF-CSR given that CSR has been seen to persist despite lung transplantation (and hence vagal denervation) (63). Other factors that may raise chemosensitivity include reduced cardiac output via reduced carotid arterial blood flow (64) and hypoxemia (via pulmonary congestion). Hypoxemia raises chemosensitivity both acutely and over time $(59,65)$.

\section{Lung volume}

Reduced end-expiratory lung volume (EELV) is another factor that can raise loop gain, destabilize breathing and promote $\operatorname{CSR}(34,35,66)$. EELV is reduced in congestive heart failure as a result of lung edema and/or pleural effusions, cardiomegaly. Lowered lung volume acts to increase loop gain by lowering the lung gas volume for buffering ventilationinduced fluctuations in $\mathrm{PCO}_{2}$ and $\mathrm{PO}_{2}(35,66)$. Lowered EELV, however, does not appear to differentiate between CHF patients and without CSR at baseline (34). Nonetheless, manipulating lung volume can have an important effect on improving CSR (35, 66). Szollosi et al (67) found that the lateral sleeping position attenuated the CSR severity (AHI) by $\sim 60 \%$ compared with the supine position. Importantly, the lateral position attenuates apneaassociated oxygen desaturation without affecting event duration. The reduced desaturation speed in lateral versus supine positions is consistent with the known elevation in lung volume in the lateral position (68), and provides indirect evidence that lung volume might be of major importance in the pathogenesis of CSR. Whether the lateral position affects other factors including cardiac output or chemosensitivity in CHF patients is currently unknown. 


\section{Behavioral state effects}

Behavioral state can also have a major effect on CSR severity. Although CSR can be observed during wakefulness, it is greatly exacerbated by the transition to sleep (69), which may appear counter-intuitive given the reduced chemosensitivity during sleep. (70-72) However, accompanying the transition from wake to sleep is an abrupt reduction in ventilatory drive (for any given $\mathrm{PaCO}_{2}$ ); likewise accompanying the transition from sleep to wake (arousal) is an abrupt increase in ventilatory drive. Thus, any oscillation in ventilatory drive that is accompanied by transitions in state (73) will be enhanced and hence ventilation is further destabilized (74). CSR is most common in light non-REM sleep (stage 1) and is most powerfully suppressed in deep non-REM sleep (slow-wave) $(67,75)$. Deeper sleep presumably promotes stable breathing via increased arousal threshold (fewer arousals/ awakenings) and reduced chemosensitivity compared to lighter sleep (70-72). The observation that a sedative (zolpidem) can greatly improve CSR in patients without CHF (76) further highlights the importance of behavioral state on ventilatory instability. CSR is also reduced but not always absent in REM sleep $(35,67,75)$; while chemosensitivity is reduced in REM (77), the arousal threshold is similar in REM to stage 1 (78) and profound (non- $\mathrm{CO}_{2}$ related) disturbances to ventilatory control are characteristic of this state. A final consideration is that sleep may promote CSR via the lowered end-expiratory lung volume that occurs with sleep onset (79).

\section{Treatment of CSR}

In patients with CHF, untreated but not treated CSR is associated with increased mortality $(8,80,81)$ leading to the view that improving severe ventilatory oscillations of CSR may promote survival. Ongoing clinical trials are assessing whether CSR treatment improves mortality. In the meantime, clinicians treat symptomatic CSR to achieve improvements in quality of life, as well as nocturnal hypoxemia, sympathoexcitation, ventricular irritability, and for small improvements in cardiac function (82-89). Although no such data exist for CSR in the ICU, we review the treatment strategies below.

\section{Treatment of heart failure}

Based on the above, therapies for the treatment of CSR first focuses on improving CHF. It is expected that treatments that improve cardiac output, decrease left atrial pressure, and improve lung volume should improve CSR. For example, intensive medical therapy that included diuretics and afterload reduction can successfully lower PCWP and improve CSR (49) (Figure 5). Similarly, beta-blockers (90-92), cardiac resynchronization therapy (43, 93), left-ventricular assist devices (94) and transplantation (95-97) have been associated with improvements in CSR over time. Rapid changes in cardiac function, as might happen in the ICU, can quickly affect CSR severity. Kara and colleagues have shown that there are acute improvements/worsening in the CSR with acute administration/withdrawal of cardiac resynchronization. (98) Although CHF treatment can be effective at resolving CSR, in many patients CSR can persist despite the most aggressive therapies including cardiac resynchronization therapy (99), left-ventricular assist devices (100), and even heart transplantation (95). Thus, additional treatments are needed for CSR. 


\section{Positive airway pressure}

Positive airway pressure, whether applied as PEEP from a mechanical ventilator or in noninvasive form as CPAP, has the potential to improve CSR acutely via multiple mechanisms:

i. Acutely increasing lung volume, which increases the gas volume for buffering ventilation-induced changes in $\mathrm{PCO}_{2}$ and $\mathrm{PO}_{2}(35,66,101)$.

ii. Stabilization of the upper airway, which may play a covert role in CSR in some patients (102).

iii. Improved hypoxemia, which in turn reduces chemosensitivity both acutely and further over time $(103,104)$. CPAP may improve oxygenation by improving microatelectasis in cardiogenic pulmonary edema (105). CPAP also improves CSRrelated desaturation independent of CSR resolution (35) presumably via increased lung volume.

iv. Improved cardiac function by lowering cardiac preload and afterload. Such effects could theoretically raise cardiac output, decrease circulatory time, and lower PCWP (and chemosensitivity) (106). However, despite improvements in afterload, cardiac output and circulatory time do not typically change with CPAP. $(25,82)$. Longterm CPAP can improve chemosensitivity over time $(82,88,103)$.

While variability in the mechanism of action may help to explain the variable effect size of CPAP in CSR $(80,83)$; it is those with the most unstable breathing pattern (the highest loop gain) that tend to respond insufficiently to CPAP (35). The majority of CPAP-related suppression of CSR is immediate $(35,87)$, consistent with major effects of CPAP acting via increased lung volume $(35,66,101)$ and relief of hypoxemia. Smaller additional suppression of CSR can be observed over time (103), are presumably via improvements in cardiac function. Such improvements in cardiac function are seen exclusively in those in whom CPAP improves CSR, and not in those in whom CPAP fails to resolve CSR nor in those with CHF but without CSR $(84,107)$. Given that CPAP is only associated with beneficial outcomes when CSR is suppressed, the early use of more aggressive therapy for CSR may be warranted.

Given the variable CSR response to CPAP, there has been increasing interested in bi-level PAP and more advanced ventilation algorithms, such as adaptive-servo ventilation (ASV). Bi-level PAP offers the advantages of CPAP but when used in a spontaneous/timed mode can provide ventilation during periods of apnea. Importantly, bi-level PAP without any back up rate during periods of apnea may de-stabilize respiration further by augmenting hyperventilation (effectively raising chemosensitivity " $G$ " in Equation 1), and can worsen central apneas during sleep (108). When applied to patients with CSR, bi-level PAP (with a backup rate) can show small further improvements in the CSR severity over CPAP. (109) ASV also provides PEEP, however, the amount of inspiratory pressure varies dynamically in order to prevent hypopneas and maintain constant minute ventilation. Inspiratory pressure increases as the patient's inspiratory effort falls, but decreases as the patient augments their inspiratory effort. Preliminary data have been promising $(81,99,110-118)$ and long term outcome data are pending (NCT01128816 and NCT00733343). 


\section{Oxygen}

Supplemental inspired oxygen therapy maintains arterial oxygenation during CSR but can also effectively resolve CSR in many patients $(116,119-121)$. Relief of hypoxemia is expected to reduce chemosensitivity ("G" in Equation 1) and thereby reduce loop gain (104). However, the effect of supplemental oxygen on CSR is heterogeneous (unlike the uniform resolution of CSR when oxygen is used for altitude-induced central sleep apnea), demonstrating that hypoxemia alone is not sufficient to explain CSR.

\section{Medications}

Ventilatory stimulants have also been employed to improve CSR in CHF patients, including acetazolamide $(69,86)$ and theophylline (122). Stimulants act to lower $\mathrm{PaCO}_{2}$ (see Equation 1) which lowers plant gain and acts to stabilize breathing (123). The administration of supplemental $\mathrm{CO}_{2}$ has a similar effect on plant gain (36), and can powerfully suppress CSR $(42,124)$. As yet, a long-term therapeutic benefit of stimulants for CHF-CSR has not yet been proven. Alternatively, the use of sedatives/hypnotics can improve CSR in patients without CHF (76); the efficacy of this approach in HF patients is unknown. A mild dose of an opiate analgesic (e.g. dihydrocodeine), as routinely administered in the ICU, can lower chemosensitivity and improve CSR and dyspnea during wakefulness $(125,126)$; however, improvements in CSR during sleep and long term benefits have not been established. Judicious administration of medications on a case-by-case basis may be warranted to treat symptomatic CSR and associated sequelae in those who do not tolerate mask-pressure based therapies.

\section{Lung volume manipulation}

One of the simplest, yet under-recognized means to improve CSR is the manipulation of body position. Positional therapy via lateral positioning $(67,75,127)$ and bed elevation (128) have potent effects on CSR severity. Given the low likelihood of "side-effects", manipulating body position to treat CSR may yield improved outcomes (Figure 6).

\section{Novel and future therapies}

Several new therapies are emerging for the treatment of CSR. Phrenic nerve stimulation, applied during the hypopnea phase of CSR, can resolve central events $(129,130)$. Dynamic $\mathrm{CO}_{2}$ therapy, applied during the hyperventilation phase of CSR to prevent hypocapnia, can resolve CSR during wakefulness without considerably raising mean ventilation $(131,132)$. Finally, denervation of the carotid-body chemoreceptors has been shown in animal studies to improve survival in CHF, and a case patient with CHF improved sleep disordered breathing, exercise capacity and quality of life $(133,134)$.

\section{ICU Management \\ General Considerations}

Although data are not available, CSR is most likely to occur during the period of ventilator weaning. When sufficient clinical progress provides for reduced sedation, and a switch to a spontaneous mode of breathing, the underlying respiratory pattern will be revealed. 
Additionally, positive end expiratory pressure (PEEP) is frequently decreased as patients move toward liberation from mechanical ventilation. As PEEP is decreased, preload and afterload will both increase which may tend to exacerbate CHF and CSR.

\section{Recognition}

The first step in ICU management of CSR is recognition. Although apneas may be noted, especially by ventilator alarms, the initial management may be focused on 1) changing alarm settings to decrease alerts, or 2) changing ventilator modes from a spontaneous mode to an assist/control mode of ventilation. (An assist/control mode will assist all spontaneous respiratory efforts, but in the absence of patient effort and apnea the ventilator will control minute ventilation by delivering a breath from the ventilator.) Alternatively, depending on the ventilator and alarm settings, some ventilators will primarily alarm for a low minute ventilation (rather than apnea) when in a spontaneous mode of ventilation. The response may be to increase the amount of pressure support provided. As explained above, this will only increase hyperventilation and further increase apnea duration. (135) Only with proper recognition can appropriate steps be taken to treat underlying heart failure, and manage the patient correctly. Respiratory therapists as well as physicians need to be familiar with the recognition of CSR.

\section{Differential diagnosis}

For the patient not on mechanical ventilation, the differential for apnea includes obstructive sleep apnea (OSA). Although endotracheal intubation will stent the upper airway open, patients on NIPPV may still have upper airway obstruction if the airway pressure (expiratory positive airway pressure, EPAP) is inadequate to hold open the upper airway. OSA is extremely common, and is likely as prevalent in patients with CHF as CSR. It too, may even more likely in the acutely decompensated patient as a result of excess edema fluid and narrowing of the pharyngeal airway. (136) Bedside evaluation of the sleeping patient should focus on signs of flow limitation, such as snoring, as well as evidence of ongoing respiratory effort during the apnea, such as paradoxical movement of the thorax and abdomen. CHF patients may have both obstructive and central sleep apnea, such that both upper airway and ventilator control require interventions.

Another important consideration is central sleep apnea due to opioids, which are commonly used both for sedation while on mechanical ventilation, and for treatment of dyspnea in CHF. (137) Central sleep apnea due to narcotics is generally believed to exhibit an ataxic, irregular pattern with reduced respiratory rate and occasional missed breaths (138). However, many patients with narcotic-induced apneas exhibit a quasi-periodic or crescendodecrescendo pattern similar to CSR (139). (FIGURE 6) The presence of CSR in the absence of hypocapnia may suggest opioid involvement.

Stroke (cerebral vascular accident, CVA) is another consideration. In fact the patient described by Dr. John Cheyne had both CHF and stroke (140). CSR is seen in $~ 20-50 \%$ of patients recovering from recent stroke (141-144). CSR is more common in patients with severe stroke, in those with concurrent CHF (low EF), and in those with longer hospital admissions (142-144). The mechanisms of stroke-related CSR are not well studied. Studies 
over half a century ago illustrated that stroke, even in the absence of CHF, can cause an increase in chemosensitivity and CSR $(145,146)$. Likewise, more recent evidence suggests that CSR in stroke is caused by an increase in chemosensitivity (as indicated by observations of lower carbon dioxide) in stroke patients with CSR versus those without CSR (142). The role of high chemosensitivity (and high loop gain) is further confirmed by the case observation that medical agents which stabilize breathing can ameliorate CSR (147). Whether treating CSR has a beneficial effect on stroke outcomes remains unclear, but available observation data illustrate that stroke-related CSR and associated sleepiness can be effectively managed with ASV (148). Thus, the new appearance of central sleep apnea in a patient with improving CHF should prompt a neurological evaluation.

\section{Treatment}

As above, if possible, the best treatment would be further efforts at heart failure treatment, especially therapies designed to lower the left atrial/pulmonary capillary wedge pressure. Other medical therapies with respiratory stimulants may or may not be practical in critically ill patients.

\section{Patient Positioning}

Given the effects of lung volume on loop gain, proper patient positioning to maximize lung volumes may have an important clinical impact. Lung volumes are greater when sitting or laying lateral than when laying supine. (149) If possible, supine patients with CSR could be moved to a different position to improve lung volumes.

\section{Ventilator Management}

For patients with CSR manifest on a pressure support mode, it is worthwhile both diagnostically and therapeutically to decrease pressure support as much as possible to assess the underlying respiratory pattern. Again, a decrement in support may decrease apneic periods, which may be sufficiently brief (and without substantial oxygen desaturation) to consider moving toward liberation from the ventilator. The most robust stress test would be to monitor the patient in the absence of pressure support and PEEP, as this will mimic the additional stress that the heart will be under once liberated from mechanical ventilation. If prolonged apneas are noted, a spontaneous mode with a back-up rate (e.g. synchronized intermittent mandatory ventilation, SIMV). Most modern ventilators can also provide adaptive-servo ventilation (ASV).

\section{Non-invasive positive pressure ventilation management}

Once extubated, the treatment algorithm may not be substantially different then the list in Section III. NIPPV can be used to provide mechanical support to the left ventricle and limit CSR, especially during sleep. Again, CPAP, Bilevel PAP with a backup rate, and ASV could all be tried. Such therapy may be necessary not only in the ICU but during the remainder of hospitalization and after discharge. 


\title{
IV. Conclusions
}

There are few data about the prevalence of CSR due to CHF in the intensive care unit. Nevertheless, CSR is expected to be highly prevalent amongst those with CHF, and treatment should focus on the underlying mechanisms by which CHF increases loop gain and promotes unstable breathing. Several important questions await further study: Does earlier recognition of CSR facilitate ventilator management and ultimately hasten weaning from mechanical ventilation? Does treatment of CSR during acute illness facilitate faster recovery? The answers to these questions could substantially impact a large number of ICU patients.

\section{Acknowledgments}

\author{
Disclosure statement: \\ Dr. Sands is supported by a National Health and Medical Research Council of Australia Early Career Fellowship \\ and R.G. Menzies award. \\ Dr. Owens is supported by the National Institutes of Health K23 HL105542. He has previously consulted for \\ Philips Respironics.
}

\section{References}

1. Ward M. Periodic respiration. A short historical note. Annals of the Royal College of Surgeons of England. 1973; 52(5):330-334. Epub 1973/05/01. [PubMed: 4268354]

2. van de Borne P, Oren R, Abouassaly C, Anderson E, Somers VK. Effect of Cheyne-Stokes respiration on muscle sympathetic nerve activity in severe congestive heart failure secondary to ischemic or idiopathic dilated cardiomyopathy. Am J Cardiol. 1998; 81(4):432-436. [PubMed: 9485132]

3. Trinder J, Merson R, Rosenberg JI, Fitzgerald F, Kleiman J, Douglas Bradley T. Pathophysiological interactions of ventilation, arousals, and blood pressure oscillations during cheyne-stokes respiration in patients with heart failure. Am J Respir Crit Care Med. 2000; 162(3 Pt 1):808-813. Epub 2000/09/16. [PubMed: 10988087]

4. Harrison TR, King CE, Calhoun JA, Harrison WG Jr. Congestive heart failure: Xx. Cheyne-Stokes respiration as the cause of paroxysmal dyspnea at the onset of sleep. Archives of Internal Medicine. 1934; 53(6):891-910.

5. Rees PJ, Clark TJ. Paroxysmal nocturnal dyspnoea and periodic respiration. Lancet. 1979; 2(81568157):1315-1317. [PubMed: 92669]

6. Berry RB, Budhiraja R, Gottlieb DJ, Gozal D, Iber C, Kapur VK, et al. Rules for scoring respiratory events in sleep: update of the 2007 AASM Manual for the Scoring of Sleep and Associated Events. Deliberations of the Sleep Apnea Definitions Task Force of the American Academy of Sleep Medicine. Journal of clinical sleep medicine : JCSM : official publication of the American Academy of Sleep Medicine. 2012; 8(5):597-619. [PubMed: 23066376]

7. Lanfranchi PA, Braghiroli A, Bosimini E, Mazzuero G, Colombo R, Donner CF, et al. Prognostic value of nocturnal Cheyne-Stokes respiration in chronic heart failure. Circulation. 1999; 99(11): 1435-1440. [PubMed: 10086966]

8. Jilek C, Krenn M, Sebah D, Obermeier R, Braune A, Kehl V, et al. Prognostic impact of sleep disordered breathing and its treatment in heart failure: an observational study. Eur J Heart Fail. 2010; 13:68-75. Epub 2010/10/22. [PubMed: 20961913]

9. Yumino D, Wang H, Floras JS, Newton GE, Mak S, Ruttanaumpawan P, et al. Relationship between sleep apnea and mortality in patients with ischemic heart failure. Heart. 2009 
10. Amir O, Reisfeld D, Sberro H, Paz H, Mintz S, Lewis BS. Implications of Cheyne-Stokes breathing in advanced systolic heart failure. Clinical cardiology. 2010; 33(3):E8-E12. [PubMed: 20155854]

11. Javaheri S, Parker TJ, Liming JD, Corbett WS, Nishiyama H, Wexler L, et al. Sleep apnea in 81 ambulatory male patients with stable heart failure. Types and their prevalences, consequences, and presentations. Circulation. 1998; 97(21):2154-2159. [PubMed: 9626176]

12. Sin DD, Fitzgerald F, Parker JD, Newton G, Floras JS, Bradley TD. Risk factors for central and obstructive sleep apnea in 450 men and women with congestive heart failure. Am J Respir Crit Care Med. 1999; 160(4):1101-1106. [PubMed: 10508793]

13. Tremel F, Pepin JL, Veale D, Wuyam B, Siche JP, Mallion JM, et al. High prevalence and persistence of sleep apnoea in patients referred for acute left ventricular failure and medically treated over 2 months. European heart journal. 1999; 20(16):1201-1209. [PubMed: 10448029]

14. Yumino D, Wang H, Floras JS, Newton GE, Mak S, Ruttanaumpawan P, et al. Prevalence and physiological predictors of sleep apnea in patients with heart failure and systolic dysfunction. $\mathrm{J}$ Card Fail. 2009; 15(4):279-285. [PubMed: 19398074]

15. Javaheri S. Sleep disorders in systolic heart failure: a prospective study of 100 male patients. The final report. International journal of cardiology. 2006; 106(1):21-28. [PubMed: 16321661]

16. MacDonald M, Fang J, Pittman SD, White DP, Malhotra A. The current prevalence of sleep disordered breathing in congestive heart failure patients treated with beta-blockers. J Clin Sleep Med. 2008; 4(1):38-42. [PubMed: 18350960]

17. Chan J, Sanderson J, Chan W, Lai C, Choy D, Ho A, et al. Prevalence of sleep-disordered breathing in diastolic heart failure. Chest. 1997; 111(6):1488-1493. [PubMed: 9187161]

18. Lanfranchi PA, Somers VK, Braghiroli A, Corra U, Eleuteri E, Giannuzzi P. Central sleep apnea in left ventricular dysfunction: prevalence and implications for arrhythmic risk. Circulation. 2003; 107(5):727-732. Epub 2003/02/13. [PubMed: 12578876]

19. Oldenburg O, Lamp B, Faber L, Teschler H, Horstkotte D, Topfer V. Sleep-disordered breathing in patients with symptomatic heart failure: a contemporary study of prevalence in and characteristics of 700 patients. Eur J Heart Fail. 2007; 9(3):251-257. [PubMed: 17027333]

20. Blackshear JL, Kaplan J, Thompson RC, Safford RE, Atkinson EJ. Nocturnal dyspnea and atrial fibrillation predict Cheyne-Stokes respirations in patients with congestive heart failure. Arch Intern Med. 1995; 155(12):1297-1302. [PubMed: 7778961]

21. Fang J, Mensah GA, Croft JB, Keenan NL. Heart failure-related hospitalization in the U.S., 1979 to 2004. Journal of the American College of Cardiology. 2008; 52(6):428-434. [PubMed: 18672162]

22. Safavi KC, Dharmarajan K, Kim N, Strait KM, Li SX, Chen SI, et al. Variation exists in rates of admission to intensive care units for heart failure patients across hospitals in the United States. Circulation. 2013; 127(8):923-929. [PubMed: 23355624]

23. Hoffman R, Agatston A, Krieger B. Cheyne-Stokes respiration in patients recovering from acute cardiogenic pulmonary edema. Chest. 1990; 97(2):410-412. [PubMed: 2298068]

24. Malhotra A, Owens RL. What is central sleep apnea? Respiratory care. 2010; 55(9):1168-1178. [PubMed: 20799999]

25. Naughton MT, Rahman MA, Hara K, Floras JS, Bradley TD. Effect of continuous positive airway pressure on intrathoracic and left ventricular transmural pressures in patients with congestive heart failure. Circulation. 1995; 91(6):1725-1731. [PubMed: 7882480]

26. Adrian ED. Afferent impulses in the vagus and their effect on respiration. The Journal of physiology. 1933; 79(3):332-358. [PubMed: 16994466]

27. Hamilton RD, Winning AJ, Horner RL, Guz A. The effect of lung inflation on breathing in man during wakefulness and sleep. Respiration physiology. 1988; 73(2):145-154. [PubMed: 3420318]

28. Hatridge J, Haji A, Perez-Padilla JR, Remmers JE. Rapid shallow breathing caused by pulmonary vascular congestion in cats. J Appl Physiol. 1989; 67(6):2257-2264. [PubMed: 2606831]

29. Lalani S, Remmers JE, MacKinnon Y, Ford GT, Hasan SU. Hypoxemia and low Crs in vagally denervated lambs result from reduced lung volume and not pulmonary edema. J Appl Physiol. 2002; 93(2):601-610. [PubMed: 12133870] 
30. Paintal AS. Mechanism of stimulation of type J pulmonary receptors. The Journal of physiology. 1969; 203(3):511-532. [PubMed: 5387024]

31. Khoo MC, Kronauer RE, Strohl KP, Slutsky AS. Factors inducing periodic breathing in humans: a general model. J Appl Physiol. 1982; 53(3):644-659. [PubMed: 7129986]

32. Edwards BA, Sands SA, Skuza EM, Stockx EM, Brodecky V, Wilkinson MH, et al. Increased peripheral chemosensitivity via dopaminergic manipulation promotes respiratory instability in lambs. Respir Physiol Neurobiol. 2008; 164(3):419-428. [PubMed: 18824144]

33. Wellman A, Jordan AS, Malhotra A, Fogel RB, Katz ES, Schory K, et al. Ventilatory control and airway anatomy in obstructive sleep apnea. Am J Respir Crit Care Med. 2004; 170(11):12251232. [PubMed: 15317668]

34. Francis DP, Willson K, Davies LC, Coats AJ, Piepoli M. Quantitative general theory for periodic breathing in chronic heart failure and its clinical implications. Circulation. 2000; 102(18):22142221. [PubMed: 11056095]

35. Sands SA, Edwards BA, Kee K, Turton A, Skuza EM, Roebuck T, et al. Loop gain as a means to predict a positive airway pressure suppression of Cheyne-Stokes respiration in patients with heart failure. Am J Respir Crit Care Med. 2011; 184(9):1067-1075. Epub 2011/08/06. [PubMed: 21816941]

36. Sands SA, Edwards BA, Kee K, Turton A, Stuart-Andrews CR, Skuza EM, et al. Loop gain explains the resolution of Cheyne-Stokes respiration using inspired $\mathrm{CO} 2$ in patients with heart failure [Abstract]. Am J Respir Crit Care Med. 2012; 185:A6697.

37. Nugent ST, Finley JP. Periodic breathing in infants: A model study. IEEE Transactions on Biomedical Engineering. 1987:482-485. BME-34. [PubMed: 3610197]

38. Wilkinson MH, Sia KL, Skuza EM, Brodecky V, Berger PJ. Impact of changes in inspired oxygen and carbon dioxide on respiratory instability in the lamb. J Appl Physiol. 2005; 98(2):437-446. [PubMed: 15475603]

39. Carley DW, Shannon DC. A minimal mathematical model of human periodic breathing. J Appl Physiol. 1988; 65(3):1400-1409. [PubMed: 3141356]

40. Mortara A, Sleight P, Pinna GD, Maestri R, Capomolla S, Febo O, et al. Association between hemodynamic impairment and Cheyne-Stokes respiration and periodic breathing in chronic stable congestive heart failure secondary to ischemic or idiopathic dilated cardiomyopathy. Am J Cardiol. 1999; 84(8):900-904. [PubMed: 10532507]

41. Oldenburg O, Bitter T, Wiemer M, Langer C, Horstkotte D, Piper C. Pulmonary capillary wedge pressure and pulmonary arterial pressure in heart failure patients with sleep-disordered breathing. Sleep Med. 2009; 10(7):726-730. [PubMed: 19135413]

42. Lorenzi-Filho G, Rankin F, Bies I, Douglas Bradley T. Effects of inhaled carbon dioxide and oxygen on cheyne-stokes respiration in patients with heart failure. Am J Respir Crit Care Med. 1999; 159(5 Pt 1):1490-1498. [PubMed: 10228116]

43. Sinha AM, Skobel EC, Breithardt OA, Norra C, Markus KU, Breuer C, et al. Cardiac resynchronization therapy improves central sleep apnea and Cheyne-Stokes respiration in patients with chronic heart failure. J Am Coll Cardiol. 2004; 44(1):68-71. Epub 2004/07/06. [PubMed: 15234409]

44. Murphy RM, Shah RV, Malhotra R, Pappagianopoulos PP, Hough SS, Systrom DM, et al. Exercise oscillatory ventilation in systolic heart failure: an indicator of impaired hemodynamic response to exercise. Circulation. 2011; 124(13):1442-1451. [PubMed: 21875912]

45. Olson TP, Frantz RP, Snyder EM, O'Malley KA, Beck KC, Johnson BD. Effects of acute changes in pulmonary wedge pressure on periodic breathing at rest in heart failure patients. Am Heart J. 2007; 153(1):104 e1-104 e7. Epub 2006/12/19. [PubMed: 17174646]

46. Topor ZL, Johannson L, Kasprzyk J, Remmers JE. Dynamic ventilatory response to CO(2) in congestive heart failure patients with and without central sleep apnea. J Appl Physiol. 2001; 91(1): 408-416. [PubMed: 11408458]

47. Javaheri S. A mechanism of central sleep apnea in patients with heart failure. N Engl J Med. 1999; 341(13):949-954. [PubMed: 10498490] 
48. Solin P, Roebuck T, Johns DP, Walters EH, Naughton MT. Peripheral and central ventilatory responses in central sleep apnea with and without congestive heart failure. Am J Respir Crit Care Med. 2000; 162(6):2194-2200. [PubMed: 11112137]

49. Solin P, Bergin P, Richardson M, Kaye DM, Walters EH, Naughton MT. Influence of pulmonary capillary wedge pressure on central apnea in heart failure. Circulation. 1999; 99(12):1574-1579. [PubMed: 10096933]

50. Poletti R, Passino C, Giannoni A, Zyw L, Prontera C, Bramanti F, et al. Risk factors and prognostic value of daytime Cheyne-Stokes respiration in chronic heart failure patients. International journal of cardiology. 2009; 137(1):47-53. [PubMed: 18691782]

51. Speksnijder L, Rutten JH, van den Meiracker AH, de Bruin RJ, Lindemans J, Hop WC, et al. Amino-terminal pro-brain natriuretic peptide (NT-proBNP) is a biomarker of cardiac filling pressures in pre-eclampsia. European journal of obstetrics, gynecology, and reproductive biology. 2010; 153(1):12-15.

52. Tschope C, Kasner M, Westermann D, Walther T, Gaub R, Poller WC, et al. Elevated NT-ProBNP levels in patients with increased left ventricular filling pressure during exercise despite preserved systolic function. J Card Fail. 2005; 11(5 Suppl):S28-S33. [PubMed: 15948097]

53. Knebel F, Schimke I, Pliet K, Schattke S, Martin S, Borges AC, et al. NT-ProBNP in acute heart failure: correlation with invasively measured hemodynamic parameters during recompensation. $\mathrm{J}$ Card Fail. 2005; 11(5 Suppl):S38-S41. [PubMed: 15948099]

54. Pudil R, Tichy M, Praus R, Blaha V, Vojacek J. NT-proBNP and echocardiographic parameters in patients with acute heart failure. Acta medica. 2007; 50(1):51-56. [PubMed: 17654836]

55. Calvin AD, Somers VK, Johnson BD, Scott CG, Olson LJ. Left atrial size, chemosensitivity, and central sleep apnea in heart failure. Chest. 2014; 146(1):96-103. [PubMed: 24522490]

56. Lorenzi-Filho G, Azevedo ER, Parker JD, Bradley TD. Relationship of carbon dioxide tension in arterial blood to pulmonary wedge pressure in heart failure. Eur Respir J. 2002; 19(1):37-40. Epub 2002/02/15. [PubMed: 11843325]

57. Manisty CH, Willson K, Wensel R, Whinnett ZI, Davies JE, Oldfield WL, et al. Development of respiratory control instability in heart failure: a novel approach to dissect the pathophysiological mechanisms. J Physiol. 2006; 577(Pt 1):387-401. [PubMed: 16959858]

58. Chenuel BJ, Smith CA, Skatrud JB, Henderson KS, Dempsey JA. Increased propensity for apnea in response to acute elevations in left atrial pressure during sleep in the dog. J Appl Physiol. 2006; 101(1):76-83. [PubMed: 16627673]

59. Szollosi I, Thompson BR, Krum H, Kaye DM, Naughton MT. Impaired pulmonary diffusing capacity and hypoxia in heart failure correlates with central sleep apnea severity. Chest. 2008; 134(1):67-72. [PubMed: 18198261]

60. Yumino D, Redolfi S, Ruttanaumpawan P, Su MC, Smith S, Newton GE, et al. Nocturnal rostral fluid shift: a unifying concept for the pathogenesis of obstructive and central sleep apnea in men with heart failure. Circulation. 2010; 121(14):1598-1605. Epub 2010/03/31. [PubMed: 20351237]

61. Lloyd TC Jr. Breathing response to lung congestion with and without left heart distension. J Appl Physiol (1985). 1988; 65(1):131-136. [PubMed: 3403458]

62. Kappagoda CT, Ravi K. The rapidly adapting receptors in mammalian airways and their responses to changes in extravascular fluid volume. Exp Physiol. 2006; 91(4):647-654. [PubMed: 16581871]

63. Solin P, Snell GI, Williams TJ, Naughton MT. Central sleep apnoea in congestive heart failure despite vagal denervation after bilateral lung transplantation. Eur Respir J. 1998; 12(2):495-498. [PubMed: 9727808]

64. Ding Y, Li YL, Schultz HD. Role of blood flow in carotid body chemoreflex function in heart failure. J Physiol. 2011; 589(Pt 1):245-258. [PubMed: 21078591]

65. Dempsey JA, Smith CA, Blain GM, Xie A, Gong Y, Teodorescu M. Role of central/peripheral chemoreceptors and their interdependence in the pathophysiology of sleep apnea. Advances in experimental medicine and biology. 2012; 758:343-349. [PubMed: 23080181]

66. Edwards BA, Sands SA, Feeney C, Skuza EM, Brodecky V, Wilkinson MH, et al. Continuous positive airway pressure reduces loop gain and resolves periodic central apneas in the lamb. Respir Physiol Neurobiol. 2009; 168(3):239-249. [PubMed: 19616133] 
67. Szollosi I, Roebuck T, Thompson B, Naughton MT. Lateral sleeping position reduces severity of central sleep apnea / Cheyne-Stokes respiration. Sleep. 2006; 29(8):1045-1051. [PubMed: 16944673]

68. Hurewitz AN, Susskind H, Harold WH. Obesity alters regional ventilation in lateral decubitus position. J Appl Physiol. 1985; 59(3):774-783. [PubMed: 4055566]

69. Fontana M, Emdin M, Giannoni A, Iudice G, Baruah R, Passino C. Effect of acetazolamide on chemosensitivity, Cheyne-Stokes respiration, and response to effort in patients with heart failure. Am J Cardiol. 2011; 107(11):1675-1680. Epub 2011/03/23. [PubMed: 21420051]

70. Douglas NJ, White DP, Weil JV, Pickett CK, Martin RJ, Hudgel DW, et al. Hypoxic ventilatory response decreases during sleep in normal men. Am Rev Respir Dis. 1982; 125(3):286-289. [PubMed: 7065538]

71. Douglas NJ, White DP, Weil JV, Pickett CK, Zwillich CW. Hypercapnic ventilatory response in sleeping adults. Am Rev Respir Dis. 1982; 126(5):758-762. [PubMed: 7149440]

72. White DP, Douglas NJ, Pickett CK, Weil JV, Zwillich CW. Hypoxic ventilatory response during sleep in normal premenopausal women. Am Rev Respir Dis. 1982; 126(3):530-533. Epub 1982/09/01. [PubMed: 7125340]

73. Domenico Pinna G, Robbi E, Pizza F, Caporotondi A, La Rovere MT, Maestri R. Sleep-wake fluctuations and respiratory events during Cheyne-Stokes respiration in patients with heart failure. J Sleep Res. 2014; 23(3):347-357. Epub 2014/03/19. [PubMed: 24635644]

74. Khoo MC, Berry RB. Modeling the interaction between arousal and chemical drive in sleepdisordered breathing. Sleep. 1996; 19(10 Suppl):S167-S169. [PubMed: 9085501]

75. Sahlin C, Svanborg E, Stenlund H, Franklin KA. Cheyne-Stokes respiration and supine dependency. Eur Respir J. 2005; 25(5):829-833. [PubMed: 15863639]

76. Quadri S, Drake C, Hudgel DW. Improvement of idiopathic central sleep apnea with zolpidem. J Clin Sleep Med. 2009; 5(2):122-129. [PubMed: 19968044]

77. Hudgel DW, Martin RJ, Johnson B, Hill P. Mechanics of the respiratory system and breathing pattern during sleep in normal humans. J Appl Physiol. 1984; 56(1):133-137. [PubMed: 6693312]

78. Edwards BA, Eckert DJ, McSharry DG, Sands SA, Desai A, Kehlmann G, et al. Clinical Predictors of the Respiratory Arousal Threshold in Patients with Obstructive Sleep Apnea. Am J Respir Crit Care Med. 2014 Epub 2014/10/17.

79. Ballard RD, Irvin CG, Martin RJ, Pak J, Pandey R, White DP. Influence of sleep on lung volume in asthmatic patients and normal subjects. Journal of applied physiology. 1990; 68(5):2034-2041. [PubMed: 2361905]

80. Arzt M, Floras JS, Logan AG, Kimoff RJ, Series F, Morrison D, et al. Suppression of central sleep apnea by continuous positive airway pressure and transplant-free survival in heart failure: a post hoc analysis of the Canadian Continuous Positive Airway Pressure for Patients with Central Sleep Apnea and Heart Failure Trial (CANPAP). Circulation. 2007; 115(25):3173-3180. [PubMed: 17562959]

81. Oldenburg O, Bitter T, Wellmann B, Natalie P, Krause B, Horstkotte D. Reduced mortality in heart failure patients with nocturnal cheyne-stokes respiration receiving adaptive servoventilation therapy. Journal of the American College of Cardiology. 2013; 61 (10_S).

82. Naughton MT, Benard DC, Rutherford R, Bradley TD. Effect of continuous positive airway pressure on central sleep apnea and nocturnal PCO2 in heart failure. Am J Respir Crit Care Med. 1994; 150(6 Pt 1):1598-1604. Epub 1994/12/01. [PubMed: 7952621]

83. Naughton MT, Liu PP, Bernard DC, Goldstein RS, Bradley TD. Treatment of congestive heart failure and Cheyne-Stokes respiration during sleep by continuous positive airway pressure. Am J Respir Crit Care Med. 1995; 151(1):92-97. Epub 1995/01/01. [PubMed: 7812579]

84. Arzt M, Floras JS, Logan AG, Kimoff RJ, Series F, Morrison D, et al. Suppression of central sleep apnea by continuous positive airway pressure and transplant-free survival in heart failure: a post hoc analysis of the Canadian Continuous Positive Airway Pressure for Patients with Central Sleep Apnea and Heart Failure Trial (CANPAP). Circulation. 2007; 115(25):3173-3180. [PubMed: 17562959] 
85. Bradley TD, Logan AG, Kimoff RJ, Series F, Morrison D, Ferguson K, et al. Continuous positive airway pressure for central sleep apnea and heart failure. N Engl J Med. 2005; 353(19):20252033. [PubMed: 16282177]

86. Javaheri S. Acetazolamide improves central sleep apnea in heart failure: a double-blind, prospective study. Am J Respir Crit Care Med. 2006; 173(2):234-237. [PubMed: 16239622]

87. Javaheri S. Effects of continuous positive airway pressure on sleep apnea and ventricular irritability in patients with heart failure. Circulation. 2000; 101(4):392-397. [PubMed: 10653830]

88. Arzt M, Schulz M, Wensel R, Montalvan S, Blumberg FC, Riegger GA, et al. Nocturnal continuous positive airway pressure improves ventilatory efficiency during exercise in patients with chronic heart failure. Chest. 2005; 127(3):794-802. [PubMed: 15764759]

89. Sharma BK, Bakker JP, McSharry DG, Desai AS, Javaheri S, Malhotra A. Adaptive servoventilation for treatment of sleep-disordered breathing in heart failure: a systematic review and meta-analysis. Chest. 2012; 142(5):1211-1221. [PubMed: 22722232]

90. Tamura A, Kawano Y, Naono S, Kotoku M, Kadota J. Relationship between beta-blocker treatment and the severity of central sleep apnea in chronic heart failure. Chest. 2007; 131(1):130 135. Epub 2007/01/16. [PubMed: 17218566]

91. Kohnlein T, Welte T. Does beta-blocker treatment influence central sleep apnoea? Respir Med. 2007; 101(4):850-853. [PubMed: 17223328]

92. Silva CP, Lorenzi-Filho G, Marcondes B, Osmundo G Jr, Mangini S, Freitas AF Jr, et al. Reduction of central sleep apnea in heart failure patients with beta-blockers therapy. Arquivos brasileiros de cardiologia. 2010; 94(2):223-229. 39-45, 6-32. [PubMed: 20428620]

93. Skobel EC, Sinha AM, Norra C, Randerath W, Breithardt OA, Breuer C, et al. Effect of cardiac resynchronization therapy on sleep quality, quality of life, and symptomatic depression in patients with chronic heart failure and Cheyne-Stokes respiration. Sleep Breath. 2005; 9(4):159-166. [PubMed: 16283229]

94. Vazir A, Hastings PC, Morrell MJ, Pepper J, Henein MY, Westaby S, et al. Resolution of central sleep apnoea following implantation of a left ventricular assist device. International journal of cardiology. 2010; 138(3):317-319. [PubMed: 18752859]

95. Mansfield DR, Solin P, Roebuck T, Bergin P, Kaye DM, Naughton MT. The effect of successful heart transplant treatment of heart failure on central sleep apnea. Chest. 2003; 124(5):1675-1681. Epub 2003/11/08. [PubMed: 14605034]

96. Braver HM, Brandes WC, Kubiet MA, Limacher MC, Mills RM Jr, Block AJ. Effect of cardiac transplantation on Cheyne-Stokes respiration occurring during sleep. Am J Cardiol. 1995; 76(8): 632-634. [PubMed: 7677096]

97. Thalhofer SA, Kiwus U, Dorow P. Influence of Orthotopic Heart Transplantation on Breathing Pattern Disorders in Patients with Dilated Cardiomyopathy. Sleep Breath. 2000; 4(3):121-126. [PubMed: 11868129]

98. Kara T, Novak M, Nykodym J, Bybee KA, Meluzin J, Orban M, et al. Short-term effects of cardiac resynchronization therapy on sleep-disordered breathing in patients with systolic heart failure. Chest. 2008; 134(1):87-93. [PubMed: 18403662]

99. Miyata M, Yoshihisa A, Suzuki S, Yamada S, Kamioka M, Kamiyama Y, et al. Adaptive servo ventilation improves Cheyne-Stokes respiration, cardiac function, and prognosis in chronic heart failure patients with cardiac resynchronization therapy. Journal of cardiology. 2012; 60(3):222227. Epub 2012/06/26. [PubMed: 22727431]

100. Padeletti M, Henriquez A, Mancini DM, Basner RC. Persistence of Cheyne-Stokes breathing after left ventricular assist device implantation in patients with acutely decompensated end-stage heart failure. J Heart Lung Transplant. 2007; 26(7):742-744. [PubMed: 17613407]

101. Krachman SL, Crocetti J, Berger TJ, Chatila W, Eisen HJ, D'Alonzo GE. Effects of nasal continuous positive airway pressure on oxygen body stores in patients with Cheyne-Stokes respiration and congestive heart failure. Chest. 2003; 123(1):59-66. [PubMed: 12527604]

102. Jobin V, Rigau J, Beauregard J, Farre R, Monserrat J, Bradley TD, et al. Evaluation of upper airway patency during cheyne-stokes breathing in heart failure patients. Eur Respir J. 2012 Epub 2012/05/19.

Crit Care Clin. Author manuscript; available in PMC 2016 July 01. 
103. Arzt M, Schulz M, Schroll S, Budweiser S, Bradley TD, Riegger GA, et al. Time course of continuous positive airway pressure effects on central sleep apnoea in patients with chronic heart failure. J Sleep Res. 2009; 18(1):20-25. [PubMed: 19250172]

104. Lloyd BB, Jukes MG, Cunningham DJ. The relation between alveolar oxygen pressure and the respiratory response to carbon dioxide in man. Quarterly journal of experimental physiology and cognate medical sciences. 1958; 43(2):214-227. [PubMed: 13542754]

105. Lenique F, Habis M, Lofaso F, Dubois-Rande JL, Harf A, Brochard L. Ventilatory and hemodynamic effects of continuous positive airway pressure in left heart failure. Am J Respir Crit Care Med. 1997; 155(2):500-505. [PubMed: 9032185]

106. Bradley TD, Holloway RM, McLaughlin PR, Ross BL, Walters J, Liu PP. Cardiac output response to continuous positive airway pressure in congestive heart failure. Am Rev Respir Dis. 1992; 145(2 Pt 1):377-382. [PubMed: 1736745]

107. Sin DD, Logan AG, Fitzgerald FS, Liu PP, Bradley TD. Effects of continuous positive airway pressure on cardiovascular outcomes in heart failure patients with and without Cheyne-Stokes respiration. Circulation. 2000; 102(1):61-66. [PubMed: 10880416]

108. Johnson KG, Johnson DC. Bilevel positive airway pressure worsens central apneas during sleep. Chest. 2005; 128(4):2141-2150. [PubMed: 16236867]

109. Kohnlein T, Welte T, Tan LB, Elliott MW. Assisted ventilation for heart failure patients with Cheyne-Stokes respiration. The European respiratory journal. 2002; 20(4):934-941. [PubMed: 12412686]

110. Oldenburg O, Schmidt A, Lamp B, Bitter T, Muntean BG, Langer C, et al. Adaptive servoventilation improves cardiac function in patients with chronic heart failure and CheyneStokes respiration. Eur J Heart Fail. 2008; 10(6):581-586. Epub 2008/05/20. [PubMed: 18486550]

111. Pepperell JC, Maskell NA, Jones DR, Langford-Wiley BA, Crosthwaite N, Stradling JR, et al. A randomized controlled trial of adaptive ventilation for Cheyne-Stokes breathing in heart failure. Am J Respir Crit Care Med. 2003; 168(9):1109-1114. [PubMed: 12928310]

112. Philippe C, Stoica-Herman M, Drouot X, Raffestin B, Escourrou P, Hittinger L, et al. Compliance with and effectiveness of adaptive servoventilation versus continuous positive airway pressure in the treatment of Cheyne-Stokes respiration in heart failure over a six month period. Heart. 2006; 92(3):337-42. Epub 2005/06/21. [PubMed: 15964943]

113. Szollosi I, O'Driscoll DM, Dayer MJ, Coats AJ, Morrell MJ, Simonds AK. Adaptive servoventilation and deadspace: effects on central sleep apnoea. J Sleep Res. 2006; 15(2):199-205. Epub 2006/05/18. [PubMed: 16704575]

114. Teschler H, Dohring J, Wang YM, Berthon-Jones M. Adaptive pressure support servoventilation: a novel treatment for Cheyne-Stokes respiration in heart failure. Am J Respir Crit Care Med. 2001; 164(4):614-619. [PubMed: 11520725]

115. Owada T, Yoshihisa A, Yamauchi H, Iwaya S, Suzuki S, Yamaki T, et al. Adaptive servoventilation improves cardiorenal function and prognosis in heart failure patients with chronic kidney disease and sleep-disordered breathing. J Card Fail. 2013; 19(4):225-232. Epub 2013/04/16. [PubMed: 23582088]

116. Yoshihisa A, Suzuki S, Miyata M, Yamaki T, Sugimoto K, Kunii H, et al. 'A single night' beneficial effects of adaptive servo-ventilation on cardiac overload, sympathetic nervous activity, and myocardial damage in patients with chronic heart failure and sleep-disordered breathing. Circ J. 2012; 76(9):2153-218. Epub 2012/07/13. [PubMed: 22785005]

117. Haruki N, Takeuchi M, Kaku K, Yoshitani H, Kuwaki H, Tamura M, et al. Comparison of acute and chronic impact of adaptive servo-ventilation on left chamber geometry and function in patients with chronic heart failure. Eur J Heart Fail. 2011; 13(10):1140-1146. Epub 2011/08/13. [PubMed: 21831914]

118. Kasai T, Usui Y, Yoshioka T, Yanagisawa N, Takata Y, Narui K, et al. Effect of flow-triggered adaptive servo-ventilation compared with continuous positive airway pressure in patients with chronic heart failure with coexisting obstructive sleep apnea and Cheyne-Stokes respiration. Circulation Heart failure. 2010; 3(1):140-148. Epub 2009/11/26. [PubMed: 19933407] 
119. Javaheri S, Ahmed M, Parker TJ, Brown CR. Effects of nasal O2 on sleep-related disordered breathing in ambulatory patients with stable heart failure. Sleep. 1999; 22(8):1101-1106. [PubMed: 10617171]

120. Hanly PJ, Millar TW, Steljes DG, Baert R, Frais MA, Kryger MH. The effect of oxygen on respiration and sleep in patients with congestive heart failure. Ann Intern Med. 1989; 111(10): 777-782. [PubMed: 2817624]

121. Krachman SL, D'Alonzo GE, Berger TJ, Eisen HJ. Comparison of oxygen therapy with nasal continuous positive airway pressure on Cheyne-Stokes respiration during sleep in congestive heart failure. Chest. 1999; 116(6):1550-1557. Epub 1999/12/14. [PubMed: 10593775]

122. Javaheri S, Parker TJ, Wexler L, Liming JD, Lindower P, Roselle GA. Effect of theophylline on sleep-disordered breathing in heart failure. N Engl J Med. 1996; 335(8):562-567. [PubMed: 8678934]

123. Edwards BA, Sands SA, Eckert DJ, White DP, Butler JP, Owens RL, et al. Acetazolamide improves loop gain but not the other physiological traits causing obstructive sleep apnoea. J Physiol. 2012; 590(Pt 5):1199-1211. [PubMed: 22219335]

124. Leung RS, Diep TM, Bowman ME, Lorenzi-Filho G, Bradley TD. Provocation of ventricular ectopy by cheyne-stokes respiration in patients with heart failure. Sleep. 2004; 27(7):1337-1343. [PubMed: 15586786]

125. Ponikowski P, Anker SD, Chua TP, Francis D, Banasiak W, Poole-Wilson PA, et al. Oscillatory breathing patterns during wakefulness in patients with chronic heart failure: clinical implications and role of augmented peripheral chemosensitivity. Circulation. 1999; 100(24):2418-2424. [PubMed: 10595954]

126. Chua TP, Harrington D, Ponikowski P, Webb-Peploe K, Poole-Wilson PA, Coats AJ. Effects of dihydrocodeine on chemosensitivity and exercise tolerance in patients with chronic heart failure. J Am Coll Cardiol. 1997; 29(1):147-152. [PubMed: 8996307]

127. Zaharna M, Rama A, Chan R, Kushida C. A case of positional central sleep apnea. J Clin Sleep Med. 2013; 9(3):265-268. [PubMed: 23493439]

128. Soll BA, Yeo KK, Davis JW, Seto TB, Schatz IJ, Shen EN. The effect of posture on CheyneStokes respirations and hemodynamics in patients with heart failure. Sleep. 2009; 32(11):14991506. [PubMed: 19928389]

129. Zhang XL, Ding N, Wang H, Augostini R, Yang B, Xu D, et al. Transvenous phrenic nerve stimulation in patients with Cheyne-Stokes respiration and congestive heart failure: a safety and proof-of-concept study. Chest. 2012; 142(4):927-934. Epub 2012/02/04. [PubMed: 22302299]

130. Ponikowski P, Javaheri S, Michalkiewicz D, Bart BA, Czarnecka D, Jastrzebski M, et al. Transvenous phrenic nerve stimulation for the treatment of central sleep apnoea in heart failure. Eur Heart J. 2012; 33(7):889-894. Epub 2011/08/23. [PubMed: 21856678]

131. Giannoni A, Baruah R, Willson K, Mebrate Y, Mayet J, Emdin M, et al. Real-time dynamic carbon dioxide administration: a novel treatment strategy for stabilization of periodic breathing with potential application to central sleep apnea. J Am Coll Cardiol. 2010; 56(22):1832-1837. Epub 2010/11/23. [PubMed: 21087712]

132. Mebrate Y, Willson K, Manisty CH, Baruah R, Mayet J, Hughes AD, et al. Dynamic CO2 therapy in periodic breathing: a modeling study to determine optimal timing and dosage regimes. J Appl Physiol. 2009; 107(3):696-706. [PubMed: 19628721]

133. Marcus NJ, Del Rio R, Schultz EP, Xia XH, Schultz HD. Carotid body denervation improves autonomic and cardiac function and attenuates disordered breathing in congestive heart failure. $\mathrm{J}$ Physiol. 2014; 592(Pt 2):391-408. [PubMed: 24247985]

134. Niewinski P, Janczak D, Rucinski A, Jazwiec P, Sobotka PA, Engelman ZJ, et al. Carotid body removal for treatment of chronic systolic heart failure. International journal of cardiology. 2013; 168(3):2506-2509. Epub 2013/04/02. [PubMed: 23541331]

135. Meza S, Mendez M, Ostrowski M, Younes M. Susceptibility to periodic breathing with assisted ventilation during sleep in normal subjects. Journal of applied physiology. 1998; 85(5):1929_ 1940. [PubMed: 9804601] 
136. White LH, Bradley TD. Role of nocturnal rostral fluid shift in the pathogenesis of obstructive and central sleep apnoea. The Journal of physiology. 2013; 591(Pt 5):1179-1193. [PubMed: 23230237]

137. Mogri M, Khan MI, Grant BJ, Mador MJ. Central sleep apnea induced by acute ingestion of opioids. Chest. 2008; 133(6):1484-1488. [PubMed: 18574293]

138. Walker JM, Farney RJ, Rhondeau SM, Boyle KM, Valentine K, Cloward TV, et al. Chronic opioid use is a risk factor for the development of central sleep apnea and ataxic breathing. Journal of clinical sleep medicine : JCSM : official publication of the American Academy of Sleep Medicine. 2007; 3(5):455-461. [PubMed: 17803007]

139. Wang D, Teichtahl H, Drummer O, Goodman C, Cherry G, Cunnington D, et al. Central sleep apnea in stable methadone maintenance treatment patients. Chest. 2005; 128(3):1348-1356. Epub 2005/09/16. [PubMed: 16162728]

140. Cheyne J. A case of apoplexy, in which the fleshy part of the heart was converted into fat. Dublin Hospital Reports. 1818; 12:216-222.

141. Nachtmann A, Siebler M, Rose G, Sitzer M, Steinmetz H. Cheyne-Stokes respiration in ischemic stroke. Neurology. 1995; 45(4):820-821. [PubMed: 7723977]

142. Nopmaneejumruslers C, Kaneko Y, Hajek V, Zivanovic V, Bradley TD. Cheyne-Stokes respiration in stroke: relationship to hypocapnia and occult cardiac dysfunction. Am J Respir Crit Care Med. 2005; 171(9):1048-1052. [PubMed: 15665317]

143. Bonnin-Vilaplana M, Arboix A, Parra O, Garcia-Eroles L, Montserrat JM, Massons J. Cheynestokes respiration in patients with first-ever lacunar stroke. Sleep disorders. 2012; 2012:257890. [PubMed: 23471518]

144. Siccoli MM, Valko PO, Hermann DM, Bassetti CL. Central periodic breathing during sleep in 74 patients with acute ischemic stroke - neurogenic and cardiogenic factors. Journal of neurology. 2008; 255(11):1687-1692. [PubMed: 19009334]

145. Brown HW, Plum F. The neurologic basis of Cheyne-Stokes Respiration. Am J Med. 1961; 30(6): 849-860.

146. Heyman A, Birchfield RI, Sieker HO. Effects of bilateral cerebral infarction on respiratory center sensitivity. Neurology. 1958; 8(9):694-700. [PubMed: 13578066]

147. Garcia-Pachon E. Severe Cheyne-Stokes Respiration In An Awake Patient After Stroke. The Internet Journal of Pulmonary Medicine. 2006; 7(1)

148. Brill AK, Rosti R, Hefti JP, Bassetti C, Gugger M, Ott SR. Adaptive servo-ventilation as treatment of persistent central sleep apnea in post-acute ischemic stroke patients. Sleep Med. 2014

149. Watson RA, Pride NB. Postural changes in lung volumes and respiratory resistance in subjects with obesity. Journal of applied physiology. 2005; 98(2):512-517. [PubMed: 15475605]

150. Kee K, Sands SA, Edwards BA, Berger PJ, Naughton MT. Positive Airway Pressure in Congestive Heart Failure. Sleep Med Clin. 2010; 5:393-405. 


\section{Key Points}

- Congestive heart failure (CHF) is a common clinical syndrome among patients in the intensive care unit (ICU), who frequently require non-invasive or mechanical ventilation.

- CHF affects control of breathing by increasing chemosensitivity and the circulatory delay, and thereby predisposes to central sleep apnea (CSA), most classically in a crescendo-decrescendo pattern of respiration known as CheyneStokes respiration (CSR).

- Few data are available to determine prevalence of CSR in the ICU, or how CSR might affect clinical management and weaning from mechanical ventilation. 


\section{Box 1}

\section{Types/Causes of CSA in the ICU}

- $\quad$ Cheyne-Stokes Respiration (CSR)

- $\quad$ Stroke/Neurological disease

- $\quad$ Narcotic Induced 


\section{Box 2}

\section{Features of Cheyne-Stokes Respiration}

- $\quad$ Waxing and Waning respiratory pattern

- Baseline hyperventilation and hypocapnia is typical

- $\quad$ Periodicity of 45-90 seconds

- $\quad$ Improved in REM and slow-wave sleep 


\section{Box 3}

Pathophysiology/Mechanisms of CSR in CHF

- $\quad$ Increased chemosensitivity, due to:

O Elevated left atrial pressure

O Hypoxemia

- $\quad$ Increased circulatory delay

- $\quad$ Low lung volumes

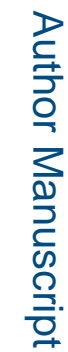

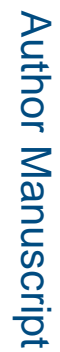

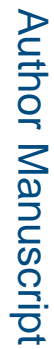

Crit Care Clin. Author manuscript; available in PMC 2016 July 01. 


\section{Box 4}

\section{Treatment of CSR}

- $\quad$ Treat CHF

Improve cardiac function, left atrial pressure, and pulmonary congestion in order to decrease circulatory delay and lower chemosensitivity

- $\quad$ Position patient to improve lung volumes

Lateral

O Bed elevation

- $\quad$ PAP therapy

Continuous PAP

O Bilevel PAP with backup rate

O Adaptive Servoventilation

- Supplemental oxygen therapy to reduce chemosensitivity

- $\quad$ Medication

Respiratory stimulants to lower $\mathrm{CO}_{2}$

O Sedatives to facilitate stable sleep

Low dose opioids to reduce chemosensitivity 
EEG (C3-A2)

Thoracic excursions

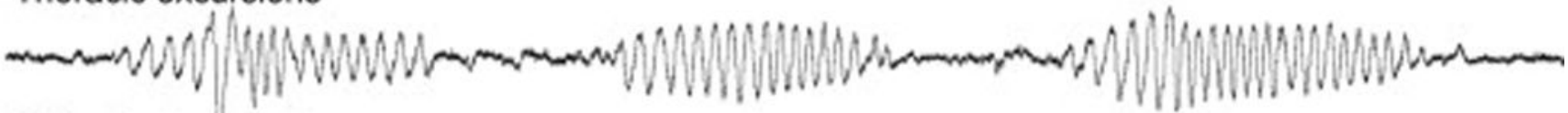
Abdominal excursions
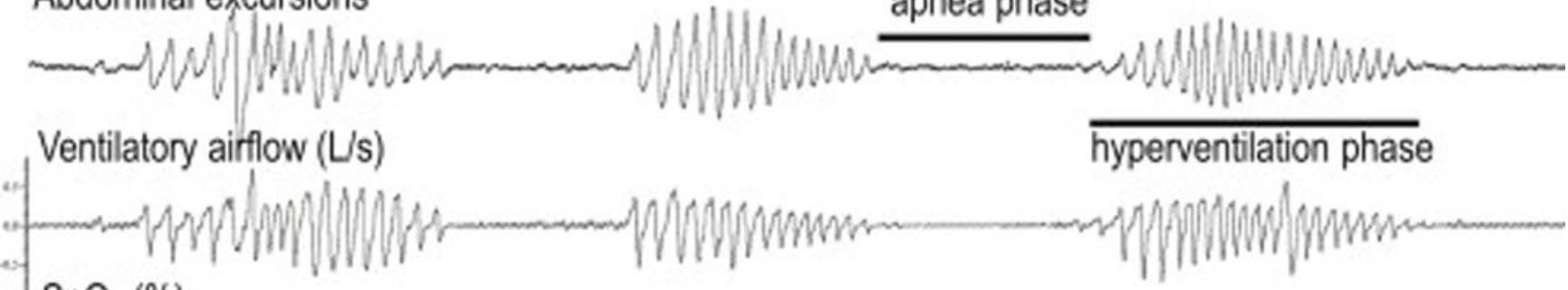

Figure 1.

Cheyne-Stokes respiration in a patient with congestive heart failure. Note crescendodecrescendo pattern of respiratory effort and airflow. The lung-to-ear circulatory delay can be approximated by the time from resumption of airflow to the start of the rise in oxygen saturation. $\mathrm{EEG}=$ electroencephalogram, $\mathrm{SpO}_{2}=$ oxygen saturation, $\mathrm{EKG}=$ electrocardiogram. 

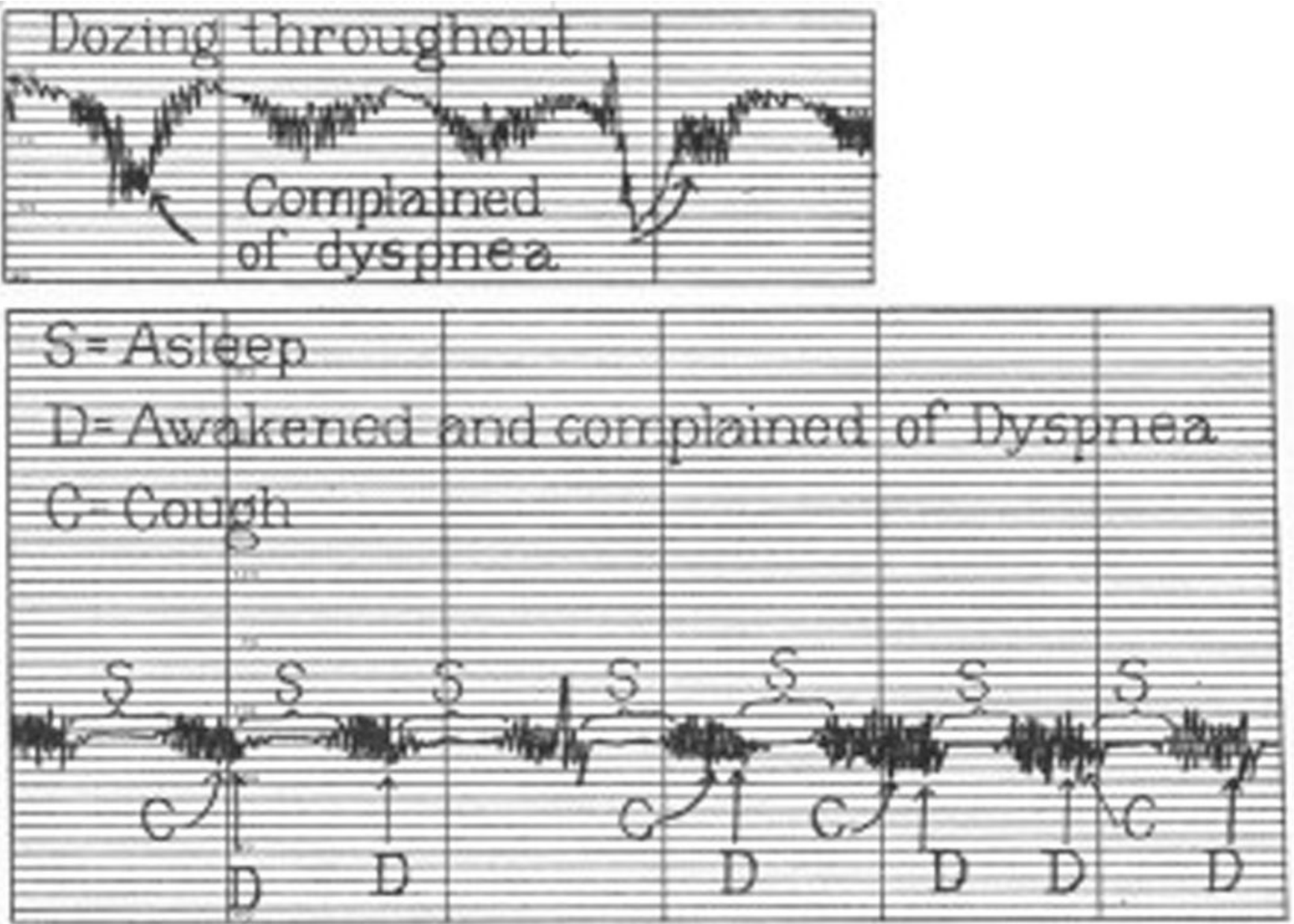

Figure 2.

Increased ventilatory drive during the hyperventilation phase of Cheyne-Stokes respiration results in dyspnea in a patient with heart failure.

Adapted from Harrison TR, King CE, Calhoun JA, Harrison WG, Jr. Congestive heart failure: Xx. Cheyne-Stokes respiration as the cause of paroxysmal dyspnea at the onset of sleep. Archives of Internal Medicine. 1934;53(6):891-910; with permission. 
A sventilation (disturbance)

Ventilation

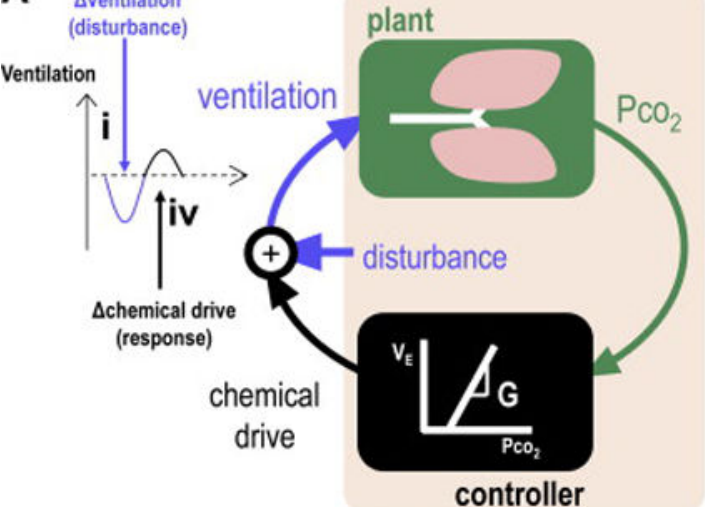

B

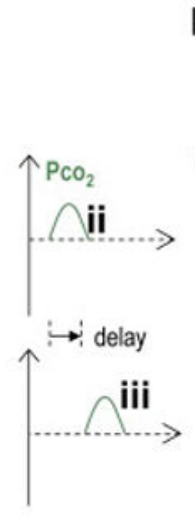

C

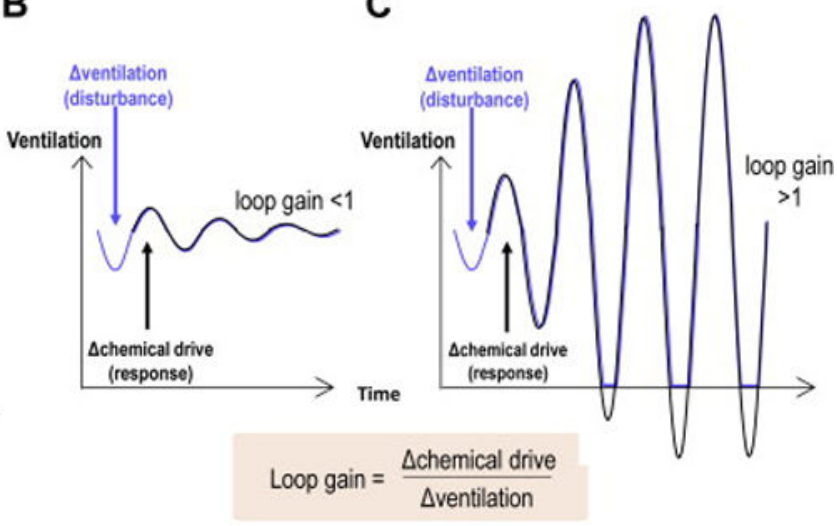

Figure 3.

Loop gain provides a framework to understand the pathophysiology of Cheyne-Stokes respiration. (A) Simplified conceptual block diagram of the respiratory control system. A disturbance to this system (i. hypoventilation) temporarily raises alveolar and arterial $\mathrm{CO}_{2}$ $\left(\mathrm{PCO}_{2}\right)$ at the lungs (ii) as determined by the "plant". After a circulatory delay (iii) the controller perceives the blood gas change and increases its output to oppose the original disturbance (iv). Whether or not this oscillation grows and manifests CSR depends on the loop gain of the system. (B) If loop gain is below 1.0, each response is smaller than the prior disturbance and transient disturbances are damped away. (C) If loop gain exceeds 1.0, each response is greater than the prior disturbance, and oscillations grow until Cheyne-Stokes respiration is established. 


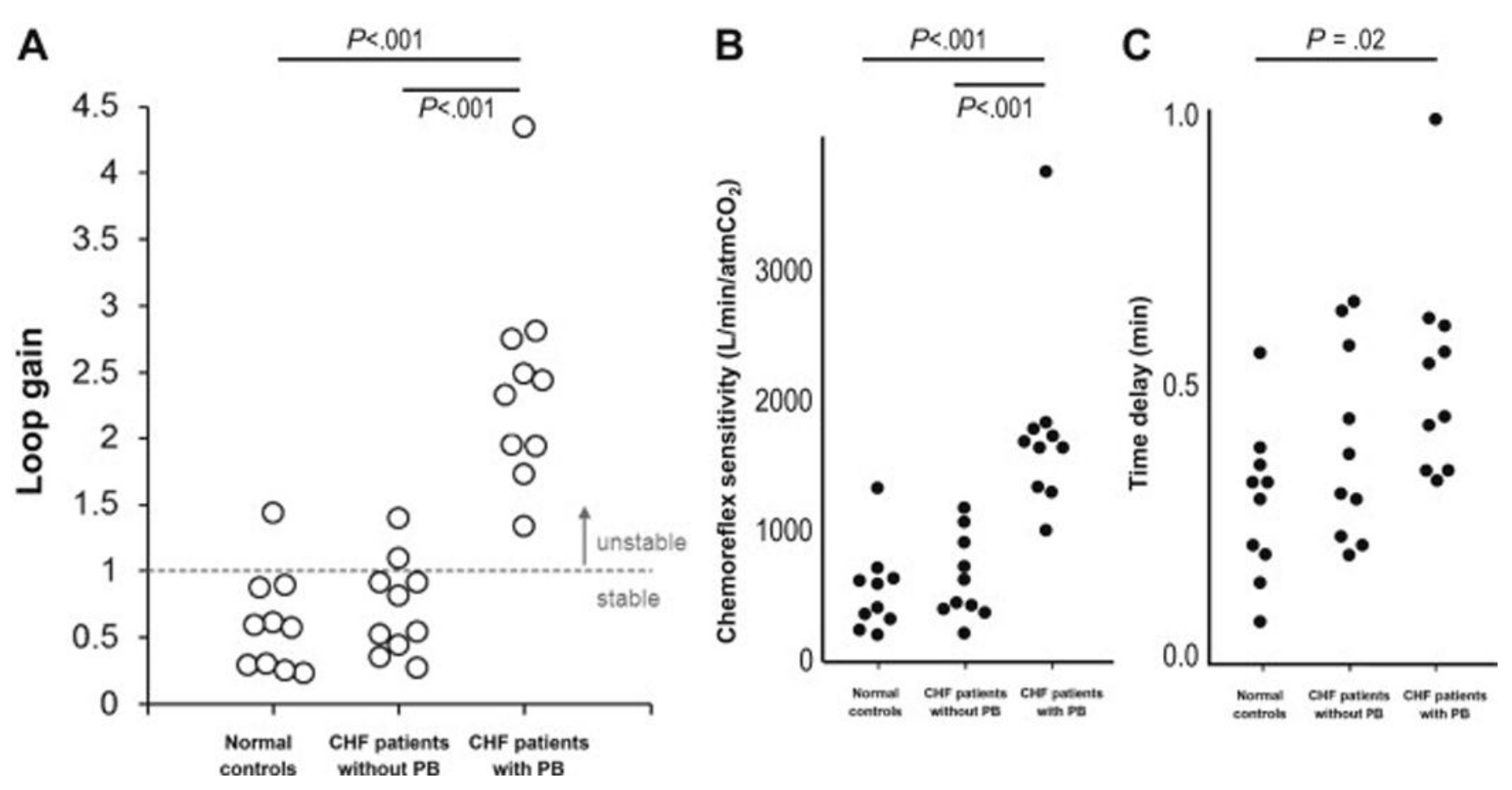

Figure 4.

Loop gain determines the presence or absence of Cheyne-Stokes respiration (periodic breathing, PB) during wakefulness. CHF patients with PB had higher loop gain compared to CHF patients without PB and healthy controls. Increased loop gain in CHF-PB was due to elevated chemosensitivity and increased circulatory delay.

Data from Francis DP, Willson K, Davies LC, Coats AJ, Piepoli M. Quantitative general theory for periodic breathing in chronic heart failure and its clinical implications. Circulation. 2000;102(18):2214-21 and Kee K, Sands SA, Edwards BA, Berger PJ, Naughton MT. Positive Airway Pressure in Congestive Heart Failure. Sleep Med Clin. 2010;5:393-405. 

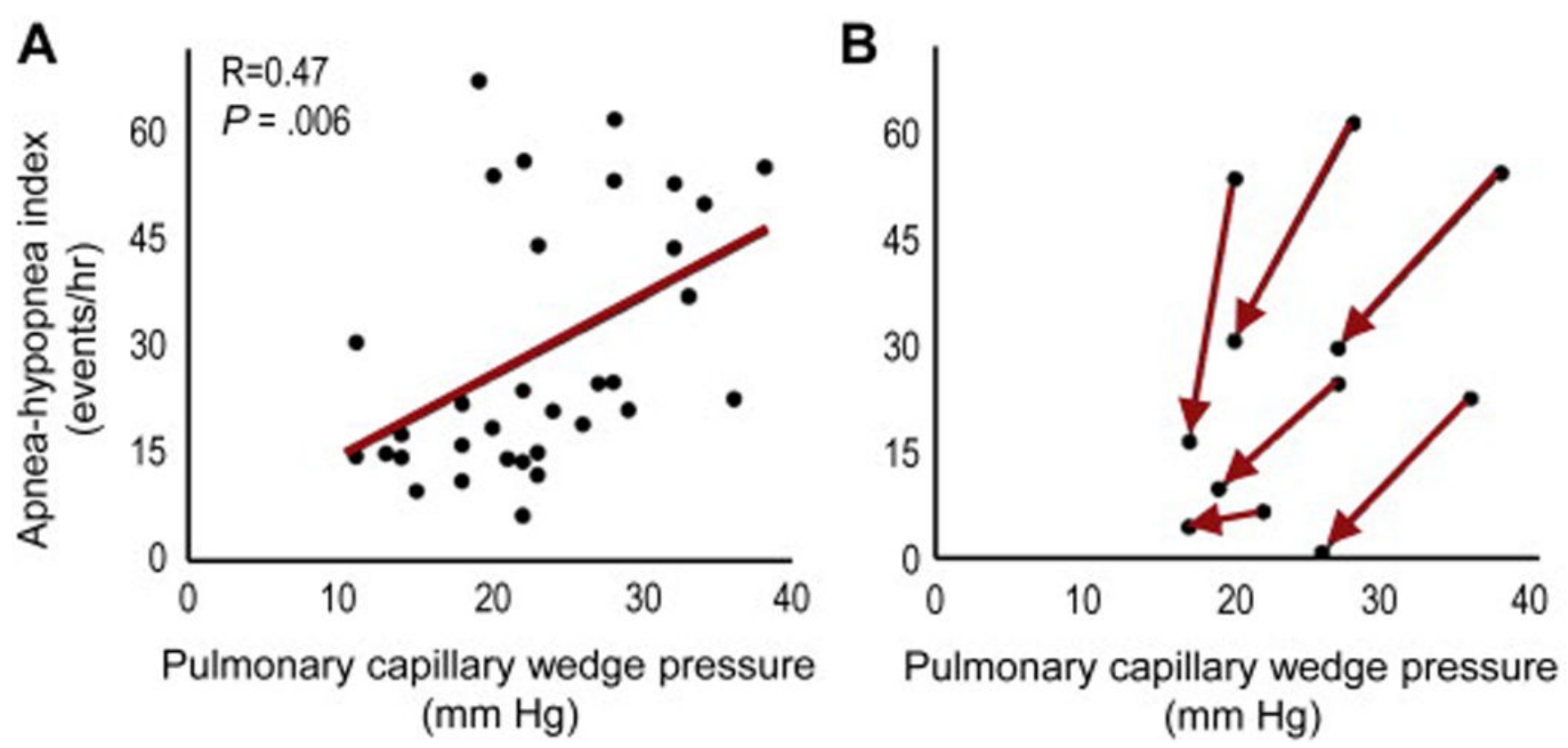

Figure 5.

Pulmonary capillary wedge pressure (PCWP) and Cheyne-Stokes respiration (CSR) during sleep. (A) Correlation between the pulmonary capillary wedge pressure and CSR severity (apnea-hypopnea index). (B) Reducing PCWP with medical intervention for heart failure improves CSR.

Adapted from Solin P, Bergin P, Richardson M, Kaye DM, Walters EH, Naughton MT. Influence of pulmonary capillary wedge pressure on central apnea in heart failure.

Circulation. 1999;99(12):1574-9; with permission. 


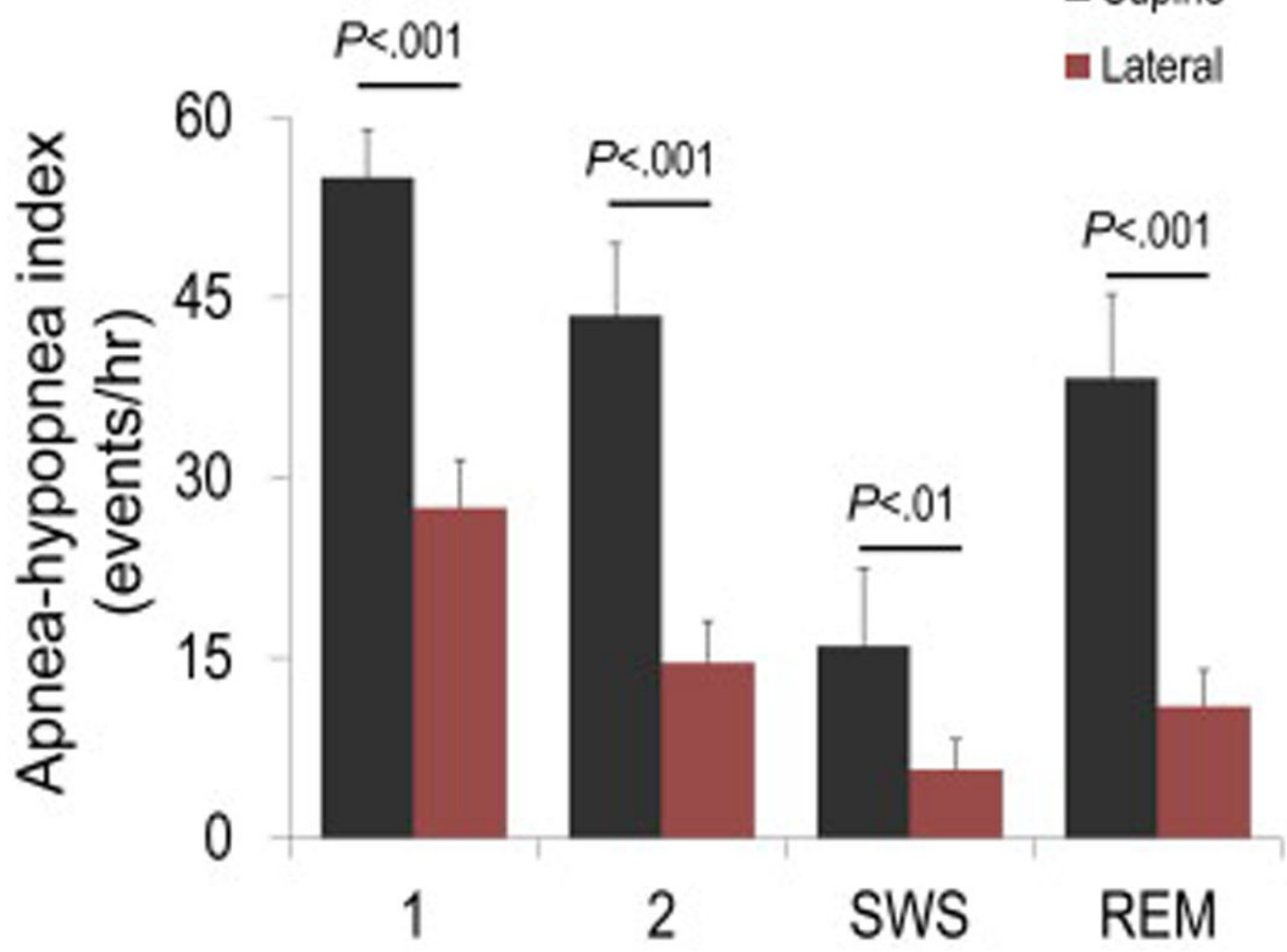

Figure 6.

Lateral position improves Cheyne-Stokes respiration (CSR) in patients with heart failure in all sleep stages. Note also that CSR severity is mild in slow wave sleep (SWS) and most severe in stage 1 non-REM.

Adapted from Szollosi I, Roebuck T, Thompson B, Naughton MT. Lateral sleeping position reduces severity of central sleep apnea / Cheyne-Stokes respiration. Sleep. 2006;29(8): 1045-51; with permission. 